\title{
Editorial
}

\section{Obesity And Nutrition In Children In Latin-America: The Italy-Mexico Joint Research Programme 2011-2013}

\section{Roberto Spinelli ${ }^{*}$}

Ambasciata d' Italia in Ciudad de Mexico, D.F., Mexico

I am very pleased to introduce this special issue of the Open Obesity Journal, dedicated to the Italy-Mexico Joint Research Programme on obesity, overweight and their determinants in children.

Italy and Mexico have a long and successful tradition of scientific and technological cooperation, reflected in a wide range of agreements, scholarships and joint researches that take place every year.

The current research is focused on understanding factors which are related to the onset of an epidemic of obesity and overweight in children, which is taking place all over the world but tends to assume sensitive dimensions in LatinAmerica and specifically in Mexico.

The research project has been approved within the framework of the Executive Programme for 2011-2013 of the Agreement of Cultural, Scientific and Technological Cooperation between Italy and Mexico, signed in 1997 by the General Directorate for Cultural Cooperation of the Italian Ministry of Foreign Affairs (MAE) and the General Direction for the Technical and Scientific Cooperation of the Secretariat for Foreign Relationships of the National Council of Science and Technology (Dirección General de Cooperación Técnica y Científica de la Secretaría de Relaciones Exteriores y del Consejo Nacional de Ciencia y Tecnología (CONACYT)).

The Italian Ministry of Foreign Affairs is financing the project for the whole period 2011-2013, given the high scientific level of the institutions and researchers involved as well as the impact that it can have in developing common

*Address correspondence to this author at the Ambasciata d'Italia a Città del Messico, Paseo de las Palmas 1994, Col. Lomas de Chapultepec, 11000 México, D.F; Tel: +52.55.55963655; Fax: +52.55.55962472;

E-mail: segreteria.messico@esteri.it research protocols and build a shared data exchange infrastructure as basis for fostering future joint research.

The goal of the project, led by a team lead by Prof. Francesco Giunta of the University of Pisa, Prof. Dario Gregori of the University of Padova and Dr.Javier Dibildox of the University of San Luis Potosí, is indeed to create a network of collaboration within the institutions of the two countries to promote the development of a common model for investigating determinants of obesity in the two countries. However, given the tight relationships existing across the entire Latin-America, models and actions foreseen in the program must be taken also as a proof-of-concept for the involvement of other countries in the Region. In this sense, the exchange of ideas and researchers across the entire Latin-America, from Chile to Argentina and Brazil, will help developing and laying the foundations for a lasting collaborative relationship and eventually lead to the implementation of an evidence-based shared vision on nutritional, educational and in general public health policies to be implemented.

This goal is fully consistent with the spirit of the Agreement between Italy and Mexico as well as the efforts of Global Public Health, which recognizes the global dimension of the obesity epidemic in children, fostering transnational, shared discussions and open research on it.

The Embassy of Italy has been supporting the project since it was conceived and officially kicked-off the initiative at the Monterrey Paediatric Conference in 2011.

I congratulate again the Open Obesity Journal for dedicating this issue to the cooperation between Italy and Mexico in such a delicate field as children's health and look forward to celebrating the completion of the project in 2013.

(C) Roberto Spinelli; Licensee Bentham Open.

This is an open access article licensed under the terms of the Creative Commons Attribution Non-Commercial License (http://creativecommons.org/licenses/by-nc/3.0/) which permits unrestricted, non-commercial use, distribution and reproduction in any medium, provided the work is properly cited. 